\title{
Effect of combined treatments and chemicalization agents on soil mycobiota in spring barley crops
}

\author{
V.A. Lavrinova*, and T.S. Polunina \\ Central Russian Branch of the FSBSI FRC n.a. I.V. Michurin, Tambov, Russia
}

\begin{abstract}
The research was carried out in the Central Russian branch of the Federal Research Center named after I.V. Michurin ". Soil samples for the study were taken from experimental plots of the Tambov Research Institute of Agriculture of the branch of the Federal State Budgetary Scientific Institution "FNTs im. I.V. Michurin ". For the first time in the northeastern part of the Central chernozem region, research is being conducted to study the microflora and microfauna of typical chernozem. The aim of the study is the effect of combined treatments, as well as the system of fertilizers on the accumulation, structure of the complex of soil phytopathogenic and saprotrophic mycobiota, as well as the microscopic population of the soil in crops of spring barley. As a result of mycological studies, a complex of soil mycobiota was revealed and the dependence of phytopathogens and saprotrophs on elements of agricultural technology was shown. Dump-surface tillage to one degree or another contributed to stabilization of the antagonistic soil mycobiota of the soil. The optimal dose of mineral fertilizer against the background of combined soil treatments has been determined, which makes it possible to successfully restrain the number of micromycetes that cause root rot. It was noted that micromycetes of the genus Pythium were most often found in soils for all crops, less than other phytopathogens. The research results have proved the peculiarity of identifying structures by the improved method.
\end{abstract}

\section{1 introduction}

The steady decline in soil fertility due to erosion and loss of organic mass is closely related to the use of the traditional method of its treatment (real tillage), which leads to the removal of plant residues from the soil surface [1]. At the same time, plant residues are a good substrate for pathogen development [2]. In addition, the intensification of grain production, the increase in the specific weight of grain crops in crop rotations create specific conditions that cause violations of the biological balance between saprophytic and pathogenic microflora in the direction of accumulation of the latter, along with an increase in the yield of grain crops, there is an increase in the infestation and harmfulness of root rot [3]. As it is known, when organic matter is deficient in the soil, the species diversity and the

\footnotetext{
${ }^{*}$ Corresponding author: lawrinowa777@mail.ru
} 
proportion of saprotrophic species decreases, and naturally for the facultative pathogens remaining in the dominant position, the cultivated plants became the food base, i.e. diseases arise [4]. As for the transition from plowing to minimal tillage, the phytosanitary situation in grain crops is deteriorating. In this regard, a fundamentally new system of agriculture is needed - a soil protection system partially with the use of a plow based on flat-cut and surface treatment of the soil with the abandonment of cover residue, crop and root residues. In terms of $\mathrm{R} \& \mathrm{D}$, one of the urgent tasks of modern intensive agriculture is the reproduction and rational use of soil fertility, and ensuring the environmental safety of protective measures for agricultural crops. In the CPR, one of the poor agrocenoses problems is the high density of infectious germs of root rot pathogens in the soil, which no longer meets the principles of ecologized plant protection. In this regard, the fight against pathogens of root rot in recent years has become problematic. Therefore, the diagnosis of soil population with phytopathogens will allow a differentiated approach to the choice of tillage technologies, a scientific approach to the use of crop rotations in farms, the integrated use of plant protection products, in particular, the potential yield of crops and the profitability of production will remain. The significance of the specific effects of chemical stressors on soil micromycete species is important for the implementation of environmental control over their behavior in the agrocenosis.

In this regard, the purpose of the study is of particular importance - the effect of combined treatments, as well as the fertilizer system on the accumulation, structure of the complex of soil phytopathogenic and saprotrophic mycobiota in spring barley crops.

\section{Materials and methods}

The reduction of root rot pathogens in the rhizosphere layer of the soil due to the use of effective chemicalization agents in combination with the methods of basic treatment was observed in the grain-fallow crop rotation (dead fallow - winter wheat - soy - barley) on the experimental plots of the Tambov Agricultural Research Institute of the branch of the FSBSI FRC n.a. I. V. Michurina. The determination of the number of harmful and useful mycobiota was carried out by a modified flotation method in the Plant Protection Laboratory of the Central Russian branch of the FSBSI FRC n.a. I. V. Michurina.

As the research material, we used:

- spring barley variety - Chakinskiy 221; - fungicides: Scarlet 0.3 1/t, Titul Duo 0.3 1/ha; - mineral fertilizer $\left(\mathrm{N}_{60} \mathrm{P}_{60} \mathrm{~K}_{60}, \mathrm{~N}_{40} \mathrm{P}_{40} \mathrm{~K}_{40}, \mathrm{~N}_{30} \mathrm{P}_{30} \mathrm{~K}_{30}\right)$. The soil is represented by a typical heavy-loamy chernozem.

The structure of soil micromycetes population was monitored in the soil at a depth of 0 $\ldots 10 \mathrm{~cm}$ against the background of combined (moldboar-nonmoldboard and moldboarsurface) treatments. Tillage, plowing and loosening with disks were carried out to a depth of 20-22 cm. Before carrying out the main processing in all variants, post-harvest disc loosening was carried out to a depth of $8-10 \mathrm{~cm}$.

The determination of the number of harmful and useful mycobiota was carried out by a modified flotation method in the Central Russian branch of the FSBSI FRC n.a. I.V. Michurin according to the methods of V.A. Lavrinova and others [5,6]. The improved method is patented under No. 2707538 Method for determining the population of soils with fungi of the genera Pythium, Fusarium and Helminthosporium using a modified flotation method. The effectiveness of this method is expressed in a more accurate determination of soil population with fungi of the genus Pythium, Fusarium and Helminthosporium compared to the traditional method of flotation. This is achieved by adding $1 \mathrm{ml}$ of distilled water instead of $0.1 \%$ solution of potassium pyrophosphate; $29 \mathrm{ml}$ of $0.1 \%$ solution of potassium pyrophosphate was added instead of $29 \mathrm{ml}$ of distilled water. 


\section{Results and discussion}

Phytoexpertise of grain seeds revealed that fungi from the genus Bipolaris, Fusarium and Alternaria, with the dominance of the first one, were pathogens of root rot. However, the soil was maximally populated with fungi from the genus Pythium, which, over the past 10 years, have a primary infection of the root system, after which the weakened plant is more strongly affected by other fungi. It was found that in the conditions of moldboarnonmoldboard treatment with $25 \%$ of plowing and $75 \%$ nonmoldboard treatment, the layer slightly enriched with crop plant residues, and moldboar-surface treatment, where plowing occupies $25 \%$, and surface treatment is $75 \%$ enriched with crop plant residues, there is a complete composition of all pathogens registered during the monitoring period. These are fungi pp. Fusarium, Bipolaris [B. sorokiniana (Sacc.) Shoemaker (syn. Helmintosporium sativum Pam., King et Bakke)], Alternaria, Pythium, semiparasitic fungi pp. Cladosporium and Rhizopus. Mold fungi (antagonists) of the genera Trichoderma (T. spp.), Penicillium Link., Aspergilluss Link. were noted, actively involved in the decomposition of plant residues and soil structure formation. In our studies, the species of these fungi was not identified, but being saprotrophs, under certain conditions, fungi are able to cause diseases of the leaves, ears and root system in grain crops, which can eventually lead to significant crop losses and plant death. In addition, in 2019, the bioclimatic potential of the Tambov region was not stable $(\mathrm{HTC}=0.3-1.7$ with a norm of $0.9-1.0)$. This pattern was observed during the entire growing season

Against the background of moldboar-nonmoldboard treatment, the harmfulness of phytopathogens increased significantly with the introduction of mineral fertilizer $\mathrm{N}_{30} \mathrm{P}_{30} \mathrm{~K}_{30}$. At the same time, the number of bipolaria reached 80 pieces, Fusarium - 127 pieces, Pythiaceae - 766 pieces, mold fungi of the genus Alternaria - 426 pieces, exceeding the threshold of harmfulness (Table 1).

Table 1. Effect of chemicalization agents on phytopathogenic mycobiota after moldboarnonmoldboard treatment, 2019.

\begin{tabular}{|c|c|c|c|c|c|c|c|c|c|}
\hline \multirow[b]{3}{*}{ 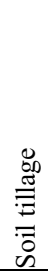 } & \multirow{3}{*}{ Fertilizer dose } & \multicolumn{2}{|c|}{ Treatment } & \multicolumn{5}{|c|}{$\begin{array}{l}\text { Number of microstructures in } 1 \mathrm{~g} \text { of air- } \\
\text { dry soil, pcs. }\end{array}$} & \multirow{3}{*}{ 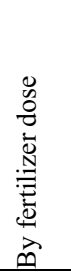 } \\
\hline & & \multirow[b]{2}{*}{ seeds } & \multirow[b]{2}{*}{ plants } & \multirow{2}{*}{ 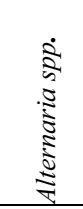 } & \multirow[b]{2}{*}{ 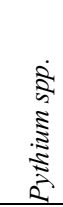 } & \multirow[b]{2}{*}{ 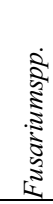 } & \multicolumn{2}{|c|}{$\begin{array}{l}\text { Bipolaris } \\
\text { spp. }\end{array}$} & \\
\hline & & & & & & & $\stackrel{D}{0}_{0}^{0}$ & 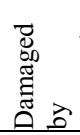 & \\
\hline \multirow{7}{*}{ 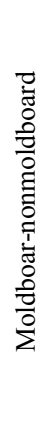 } & \multirow{2}{*}{$\mathrm{N}_{60} \mathrm{P}_{60} \mathrm{~K}_{60}$} & $\begin{array}{l}\text { Scarlet } \\
0.31 / \mathrm{t}\end{array}$ & $\begin{array}{l}\text { Titul Duo } \\
0.251 / \text { ha }\end{array}$ & 53 & 240 & 13 & 7 & 27 & \multirow{2}{*}{820} \\
\hline & & $\begin{array}{c}\text { Scarlet } \\
0.31 / \mathrm{t} \\
\end{array}$ & $\begin{array}{l}\text { without } \\
\text { treatment }\end{array}$ & 113 & 367 & 27 & 0 & 27 & \\
\hline & \multirow{2}{*}{$\mathrm{N}_{40} \mathrm{P}_{40} \mathrm{~K}_{40}$} & $\begin{array}{l}\text { Scarlet } \\
0.31 / \mathrm{t}\end{array}$ & $\begin{array}{l}\text { Titul Duo } \\
0.25 \mathrm{l} / \mathrm{ha}\end{array}$ & 113 & 260 & 13 & 0 & 7 & \multirow{2}{*}{1060} \\
\hline & & $\begin{array}{c}\text { Scarlet } \\
0.31 / \mathrm{t}\end{array}$ & $\begin{array}{l}\text { without } \\
\text { treatment }\end{array}$ & 207 & 427 & 40 & 0 & 60 & \\
\hline & \multirow{2}{*}{$\mathrm{N}_{30} \mathrm{P}_{30} \mathrm{~K}_{30}$} & $\begin{array}{l}\text { Scarlet } \\
0.31 / \mathrm{t}\end{array}$ & $\begin{array}{l}\text { Titul Duo } \\
0.25 \mathrm{l} / \mathrm{ha} \\
\end{array}$ & 133 & 293 & 40 & 53 & 73 & \multirow{2}{*}{1399} \\
\hline & & $\begin{array}{l}\text { Scarlet } \\
0.31 / \mathrm{t}\end{array}$ & $\begin{array}{l}\text { without } \\
\text { treatment }\end{array}$ & 293 & 473 & 87 & 27 & 87 & \\
\hline & \multicolumn{3}{|c|}{ Total number } & 912 & 2060 & 220 & 87 & 281 & 3279 \\
\hline
\end{tabular}

Here, the maximum number of conidia Bipolaris spp. with signs of degradation (decomposition) increased significantly (160 pcs.), due to the maximum number of microstructures of suppressor fungi. After treatment, where, in addition to the soil overturning, the disks were loosened, thereby preserving sufficient moisture for the 
mineralization of plant residues, which acted ruinously for more specialized phytopathogens of the Bipolaris type than for relatively competitive soil saprotrophs from the Fusarium genus.

Against the background of $\mathrm{N}_{60} \mathrm{P}_{60} \mathrm{~K}_{60}$ the harmful mycobiota was maximally reduced: fungi pp. Alternaria up to 166 pieces, Pythium up to 607 pieces and Fusarium up to 40 units, and only the last variant did not exceed the threshold number. The genus Bipolaris was completely suppressed by antagonists after the introduction of $\mathrm{N}_{40} \mathrm{P}_{40} \mathrm{~K}_{40}$. Although an increase in the fertilization background after surface tillage in our studies led to an increase in the population density of soil fungi. According to an authoritative source, with prolonged use of mineral fertilizers, the number of fungi in the permanent fallow of sod-podzolic soil increased by 1.4 times [7].

As a result of the mycological analysis of soil samples, it was found that the introduction of mineral nutrition at a dose of $\mathrm{N}_{60} \mathrm{P}_{60} \mathrm{~K}_{60}$ stimulated the overall biological and antagonistic activity of the soil, served as real prerequisites for the stabilization and reduction of the number of harmful organisms ( 820 pcs.) in relation to the background of fertilization $\mathrm{N}_{30} \mathrm{P}_{30} \mathrm{~K}_{30}$ (1399 pcs.), which was more active. There was a dependence of Helminthosporium fungi on Fusarium fungi, i.e. if the number of some increased, the saturation of the soil with others decreased and vice versa. It was found that the dominant species in the complex of isolated soil fungi were species of the genera Pythium spp. (2060 pieces). Micromycetes of the genus Bipolaris ( $87 \mathrm{pcs}$.) showed weak activity.

There was a semi-parasitic fungus from the genus Cladosporium with predominant signs of saprophytism: against the background of a doubled mineral application of 300 pieces, $\mathrm{N}_{40} \mathrm{P}_{40} \mathrm{~K}_{40}-180$ pieces, with $\mathrm{N}_{30} \mathrm{P}_{30} \mathrm{~K}_{30}$, the occurrence of micromycetes decreased slightly to 147 specimens. Another semi-parasitic fungus Rhizopus (240 pieces) was often found. To a greater extent, the pathogen was presented after the introduction of double mineral nutrition (100 copies), slightly weaker after the dose of $\mathrm{N}_{30} \mathrm{P}_{30} \mathrm{~K}_{30}$ (87 specimens), minimally against the background of $\mathrm{N}_{40} \mathrm{P}_{40} \mathrm{~K}_{40}$ ( 53 specimens).

As for the micromycetes of representatives of the genus Fusarium, some species of the genera Bipolaris, Alternaria, Cladosporium, they have a wide range of adaptive reactions. This causes their saprophytic phase of growth, as well as the weakening of plants - the transition to parasitism on their tissues. In particular, the spring barley of the Central Part of Russia shows root rot, which is widely confined to the spatial and temporal frequency of occurrence. In addition, the weather conditions of the studied year had a wide distribution on dark-colored fungi of genus Cladosporium Link ex Fr., less than of genera Alternaria (Fr.) Keissl, Bipolaris. According to another source, the most common micromycetes in the studied agricultural soils, located in the Kamyzyaksky district of the Astrakhan region, were representatives of the genus Aspergillus, then - Penicillium and Alternaria [8].

On the one hand, the suppressive properties of the soil were determined by the species of the genera Penicillium spp., Aspergillus spp. (160 pcs.), Trichoderma spp. (34 pcs.), which have antagonistic properties. On the other hand, there was a pattern among these groups of fungi-saprophytes and semi-parasitic fungi from the genus Cladosporium, which could be harmful at high humidity and low temperature during the emergence of seedlings (poisoning of the germ and seed sprouts, thinning of seedlings, curvature of seedlings, unproductive bushiness), maturation (white-spined, black ear) and crop storage (darkening of grain in the germ zone, use of grain nutrients) of grain crops. At the same time, the soil layer was maximally permeated with the micelial network of the Rhizopus micromycete, the causative agent of black mold. The dose of $\mathrm{N}_{30} \mathrm{P}_{30} \mathrm{~K}_{30}$ mainly stimulated the presence of saprotrophic micromycetes (180 pcs.) (Table 2). 
Table 2. Effect of chemicalization agents on saprotrophic mycobiota after moldboar-nonmoldboard treatment, 2019.

\begin{tabular}{|c|c|c|c|c|c|c|}
\hline \multirow[b]{2}{*}{ 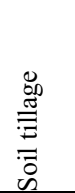 } & \multirow[b]{2}{*}{$\begin{array}{l}\text { Fertilizer } \\
\text { dose }\end{array}$} & \multicolumn{2}{|c|}{ Treatment } & \multicolumn{3}{|c|}{$\begin{array}{l}\text { Number of microstructures in } 1 \mathrm{~g} \text { of } \\
\text { air-dry soil, pcs. }\end{array}$} \\
\hline & & seeds & plants & $\begin{array}{l}\text { Penicilliu } \\
\text { m spp. } \\
\text { Aspergill } \\
\text { us spp. }\end{array}$ & $\begin{array}{l}\text { Trichoderm } \\
\text { a spp. }\end{array}$ & $\begin{array}{l}\text { By dose } \\
\text { of } \\
\text { fertilize } \\
r\end{array}$ \\
\hline \multirow{7}{*}{ 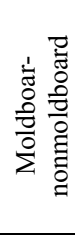 } & \multirow{2}{*}{$\begin{array}{l}\mathrm{N}_{60} \mathrm{P}_{60} \mathrm{~K}_{6} \\
0\end{array}$} & Scarlet $0.31 / \mathrm{t}$ & Titul Duo 0.25 1/ha & 0 & 7 & \multirow{2}{*}{7} \\
\hline & & Scarlet $0.31 / \mathrm{t}$ & Without treatment & 0 & 0 & \\
\hline & \multirow{2}{*}{$\begin{array}{l}\mathrm{N}_{40} \mathrm{P}_{40} \mathrm{~K}_{4} \\
0\end{array}$} & Scarlet $0.31 / \mathrm{t}$ & Titul Duo 0.25 1/ha & 0 & 7 & \multirow{2}{*}{7} \\
\hline & & Scarlet $0.3 \mathrm{l} / \mathrm{t}$ & Without treatment & 0 & 0 & \\
\hline & \multirow{3}{*}{$\begin{array}{l}\mathrm{N}_{30} \mathrm{P}_{30} \mathrm{~K}_{3} \\
0\end{array}$} & Scarlet $0.3 \mathrm{l} / \mathrm{t}$ & Titul Duo 0.25 1/ha & 67 & 13 & \multirow{2}{*}{180} \\
\hline & & Scarlet $0.31 / \mathrm{t}$ & Without treatment & 93 & 7 & \\
\hline & & \multicolumn{2}{|c|}{ Total number } & 160 & 34 & 194 \\
\hline
\end{tabular}

In the soil samples, Erysiphales ( 74 pcs.), rust (41 pcs.), smut (17 pcs.) micromycetes affecting the vegetative organs of grain crop plants were also detected. Representatives of the nanofauna - infusoria, were identified, the number of which after the introduction of $\mathrm{N}_{30} \mathrm{P}_{30} \mathrm{~K}_{30}$ (20 specimens) and $\mathrm{N}_{40} \mathrm{P}_{40} \mathrm{~K}_{40}$ (20 specimens) remained to a greater extent, against the background of $\mathrm{N}_{60} \mathrm{P}_{60} \mathrm{~K}_{60}$ (7 specimens) to a lesser extent. In particular, infusoria eat ready-made organic substances, i.e., in this case, fungal mycelium and bacteria, which were not possible to count, since they were mainly found in the form of microcolonies, consisting of several tens, and sometimes several thousand cells. Moreover, the analysis did not require their number, but only their component in the food chain. Representatives of the mesofauna, soil mites and Aschelminthes were absent in the system of moldboar-nonmoldboard treatment.

In the moldboar-surface tillage method, when applying fertilizer $\mathrm{N}_{60} \mathrm{P}_{60} \mathrm{~K}_{60}$, pathogens of common ( 80 pcs.), Fusarium ( 80 pcs.) root rot, $\mathrm{N}_{30} \mathrm{P}_{30} \mathrm{~K}_{30}$ - Pythiaceae (867 pcs.) and alternaria infection (300 pcs.), with an excess of NA, accumulated to the maximum (Table $3)$.

Table 3. Effect of chemicalization agents on phytopathogenic mycobiota after moldboar-surface treatment, 2019.

\begin{tabular}{|c|c|c|c|c|c|c|c|c|c|}
\hline \multirow{3}{*}{$\begin{array}{l}\text { Soi } \\
1 \\
\text { till } \\
\text { age }\end{array}$} & \multirow[b]{3}{*}{$\begin{array}{l}\text { Fertilizer } \\
\text { dose }\end{array}$} & \multicolumn{2}{|c|}{ Treatment } & \multicolumn{5}{|c|}{$\begin{array}{l}\text { Number of microstructures in } 1 \mathrm{~g} \text { of air- } \\
\text { dry soil, pes. }\end{array}$} & \multirow{3}{*}{$\begin{array}{l}\text { By } \\
\text { dose } \\
\text { of } \\
\text { fertil } \\
\text { izer }\end{array}$} \\
\hline & & \multirow[b]{2}{*}{ seeds } & \multirow[b]{2}{*}{ plants } & \multirow[b]{2}{*}{$\begin{array}{l}\text { Alter } \\
\text { naria } \\
\text { spp. }\end{array}$} & \multirow[b]{2}{*}{$\begin{array}{l}\text { Pythi } \\
\text { um } \\
\text { spp. }\end{array}$} & \multirow[b]{2}{*}{$\begin{array}{l}\text { Fusa } \\
\text { rium } \\
\text { spp. }\end{array}$} & \multicolumn{2}{|c|}{ Bipolaris spp. } & \\
\hline & & & & & & & $\begin{array}{l}\text { Ac } \\
\text { tiv } \\
\mathrm{e}\end{array}$ & $\begin{array}{l}\text { Damag } \\
\text { ed by } \\
\text { antago } \\
\text { nists }\end{array}$ & \\
\hline \multirow{7}{*}{$\begin{array}{c}\text { Mo } \\
\text { ldb } \\
\text { oar } \\
\text { - } \\
\text { sur } \\
\text { fac } \\
\text { e }\end{array}$} & \multirow{2}{*}{$\mathrm{N}_{60} \mathrm{P}_{60} \mathrm{~K}_{60}$} & Scarlet $0.31 / \mathrm{t}$ & Titul Duo 0.25 1/ha & 13 & 173 & 27 & 27 & 33 & \multirow{2}{*}{846} \\
\hline & & Scarlet0.3 1/t & without treatment & 93 & 407 & 53 & 53 & 73 & \\
\hline & \multirow{2}{*}{$\mathrm{N}_{40} \mathrm{P}_{40} \mathrm{~K}_{40}$} & Scarlet $0.31 / \mathrm{t}$ & Titul Duo 0.25 1/ha & 47 & 227 & 13 & 13 & 73 & \multirow{2}{*}{980} \\
\hline & & Scarlet $0.31 / \mathrm{t}$ & without treatment & 93 & 467 & 60 & 60 & 40 & \\
\hline & \multirow{2}{*}{$\mathrm{N}_{30} \mathrm{P}_{30} \mathrm{~K}_{30}$} & Scarlet $0.31 / \mathrm{t}$ & Titul Duo 0.25 1/ha & 80 & 307 & 13 & 13 & 47 & \multirow{2}{*}{1259} \\
\hline & & Scarlet $0.31 / \mathrm{t}$ & without treatment & 220 & 560 & 33 & 33 & 87 & \\
\hline & \multicolumn{3}{|c|}{ Total number } & 546 & 2141 & 199 & $\begin{array}{c}19 \\
9\end{array}$ & 353 & 3085 \\
\hline
\end{tabular}

At the same time, the manifestation of Fusarium and Helminthosporiums (46 pcs.) was observed to a lesser extent against the background of $\mathrm{N}_{30} \mathrm{P}_{30} \mathrm{~K}_{30}$ without variant differences, and against the background of $\mathrm{N}_{60} \mathrm{P}_{60} \mathrm{~K}_{60}$ Alternaria blight (106 pcs.) and pythiosis $(600$ pcs.). The decrease in the number of Fusarium fungi to the threshold level and lower, most 
likely, in addition to mineral nutrition, was strongly influenced by soil and air drought, in particular, there was practically no mineralization of plant residues. However, the total number of microstructures of fusarium and Helminthosporium fungi for all variants of applied fertilizers was in equilibrium. It should be borne in mind that, taking into account the number of a particular group, it is possible to judge only the physiological potential of soil microorganisms, but not its implementation in natural conditions [9].

The application of nitrogen fertilizers in combination with phosphorus and potassium fertilizers $\left(\mathrm{N}_{60} \mathrm{P}_{60} \mathrm{~K}_{60}\right)$ stimulated the general antagonistic and biological activity of the soil, served as real prerequisites for the stabilization and reduction of the number of harmful organisms (846 units) in relation to the background of fertilization with $\mathrm{N}_{30} \mathrm{P}_{30} \mathrm{~K}_{30}-1259$ pieces. For all variants, there was no dependence of Helminthosporium fungi on Fusarium fungi, since their number was in equilibrium with respect to each other. This treatment system was dominated by the species of fungi Pythium spp. (2141 pieces).

The number of Bipolaris spp. conidia (134 pieces) with signs of degradation (decomposition) increases to the maximum with the introduction of the mineral nutrition complex $\mathrm{N}_{30} \mathrm{P}_{30} \mathrm{~K}_{30}$. Useful soil mycoflora was represented by fungi Penicillium spp., Aspergillus spp. (80 pieces) and micromycete Trichoderma (41 pieces). The maximum number of mold fungi $\left(60\right.$ pcs.) was noted against the background of $\mathrm{N}_{40} \mathrm{P}_{40} \mathrm{~K}_{40}$, Trichoderma spp. - larger number (27 pcs.) after the application of $\mathrm{N}_{60} \mathrm{P}_{60} \mathrm{~K}_{60}$ (Table 4).

Table 4. Effect of chemicalization agents on saprotrophic mycoflora after moldboar-surface treatment, 2019.

\begin{tabular}{|c|c|c|c|c|c|c|}
\hline \multirow[b]{2}{*}{ 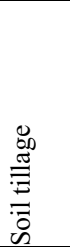 } & \multirow[b]{2}{*}{$\begin{array}{c}\text { Fertilizer } \\
\text { dose }\end{array}$} & \multicolumn{2}{|c|}{ Treatment } & \multicolumn{3}{|c|}{$\begin{array}{l}\text { Number of microstructures in } 1 \mathrm{~g} \text { of air } \\
\text { dry soil, pcs. }\end{array}$} \\
\hline & & seeds & plants & 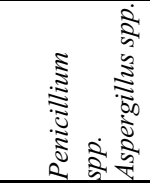 & 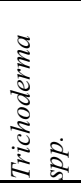 & 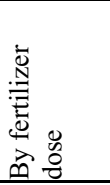 \\
\hline \multirow{7}{*}{ 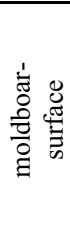 } & \multirow{2}{*}{$\mathrm{N}_{60} \mathrm{P}_{60} \mathrm{~K}_{60}$} & Scarlet $0.31 / \mathrm{t}$ & Titul Duo 0.25 1/ha & 20 & 20 & \multirow{2}{*}{47} \\
\hline & & Scarlet $0.31 / \mathrm{t}$ & Without treatment & 0 & 7 & \\
\hline & \multirow{2}{*}{$\mathrm{N}_{40} \mathrm{P}_{40} \mathrm{~K}_{40}$} & Scarlet $0.31 / \mathrm{t}$ & Titul Duo 0.25 1/ha & 0 & 7 & \multirow{2}{*}{67} \\
\hline & & Scarlet $0.31 / \mathrm{t}$ & Without treatment & 60 & 0 & \\
\hline & \multirow{2}{*}{$\mathrm{N}_{30} \mathrm{P}_{30} \mathrm{~K}_{30}$} & Scarlet $0.31 / \mathrm{t}$ & Titul Duo 0.25 1/ha & 0 & 7 & \multirow{2}{*}{7} \\
\hline & & Scarlet $0.31 / \mathrm{t}$ & Without treatment & 0 & 0 & \\
\hline & \multicolumn{3}{|c|}{ Total number } & 80 & 41 & 121 \\
\hline
\end{tabular}

According to an authoritative source, the use of mineral fertilizers stimulates the growth of the saprophyte population [7]. According to the foreign author, representatives of the genus Alternaria prefer conditions of organic background, and micromycetes of the genera Fusarium, Aspergillus have zero contribution in the variant with an organic background [10].

A semi-parasitic fungus from the genus Cladosporium with predominant signs of saprophytism was often found: 454 pieces against the background of double mineral application, $\mathrm{N}_{40} \mathrm{P}_{40} \mathrm{~K}_{40}-147$ pieces, with $\mathrm{N}_{30} \mathrm{P}_{30} \mathrm{~K}_{30}-460$ specimens. Another semiparasitic fungus Rhizopus (155 pieces) was identified. To a greater extent, the pathogen was presented after the introduction of $\mathrm{N}_{30} \mathrm{P}_{30} \mathrm{~K}_{30}$ (87 specimens), slightly weaker against the background of doubled mineral nutrition (58 specimens) and minimally (10 specimens), after the dose of $\mathrm{N}_{40} \mathrm{P}_{40} \mathrm{~K}_{40}$. In the soil samples, Erysiphales (120 pcs.), rust ( 7 pcs.), smut (13 pcs.) micromycetes affecting the vegetative organs of grain crop plants were also detected.

In our studies, the microscopic population of the soil after moldboar-surface treatment was extremely numerous and diverse in relation to the moldboar-nonmoldboar treatment. 
The majority of them exist as saprophytes, using organic substances for food or parasitizing other higher and lower organisms (Fig. 1).

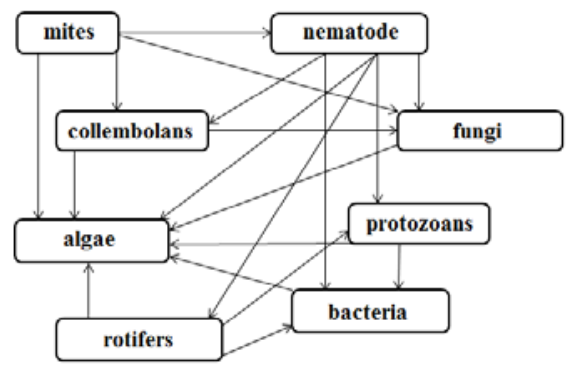

Fig. 3. Scheme of the food chain of microorganisms (according to V.A. Lavrinova)

Representatives of the nanofauna - infusoria were identified, the number of which after the introduction of $\mathrm{N}_{60} \mathrm{P}_{60} \mathrm{~K}_{60}(33$ specimens) remained to a greater extent, against the background of $\mathrm{N}_{40} \mathrm{P}_{40} \mathrm{~K}_{40}$ (20 specimens) to a lesser extent and were rarely found at a dose of $\mathrm{N}_{30} \mathrm{P}_{30} \mathrm{~K}_{30}$ ( 7 specimens). Eating fungal mycelium and bacteria, the infusoria served as food for the nematodes. The proportion of soil mites $(27$ specimens $)$ in relation to nematodes ( 7 specimens) was the maximum. Most likely, this is due to the fact that there are predators among mites, which, feeding on fungi, also ate nematodes, and in some way brought benefits, freeing the plant world from harmful microorganisms. However, one should not forget that they were also carriers of phytopathogenic microflora.

Among the threadworms in the soil, most likely, there were predators that ate protozoa, rotifers and their own kind, and hemi-saprobionts that ate bacteria, fungi and soil algae. This indicates that no forms were identified in the soil samples by representatives of the above-mentioned microscopic population. Numerous bacterial colonies were also identified.

Monitoring of the population of soil phytopathogens in the agrocenosis of grain crops cultivated on soy showed that disking, compared with loosening against the background of soil overturning, decreased slightly, only by 1.1 times. Although the group of saprophyte fungi was more active after moldboar-nonmoldboar treatment (194 pieces) in relation to the moldboar-surface treatment (121 pieces). However, the microscopic population of the soil was represented as much as possible (94 specimens) after moldboar-surface treatment (infusoria, mites, nematodes). This was facilitated by the accumulation of a large amount of plant residues in the soil surface layer. Only infusoria (47 specimens) were identified after the moldboar-nonmoldboar treatment. Most likely, in general experience, phytopathogens were strongly influenced not only by suppressor fungi, but also by microorganisms for which soil micromycetes, along with bacteria, were food. In addition, the presence of a weak population of the fungus Trichoderma was noted, most likely due to the high number of the parasite fungus Rhizopus, as well as due to unstable weather factors that differed in regularity throughout the growing season.

As for the applied mineral nutrition, after the treatments carried out, harmful microscopic fungi accumulated more actively against the background of $\mathrm{N}_{60} \mathrm{P}_{60} \mathrm{~K}_{60}$, useful against the background of $\mathrm{N}_{30} \mathrm{P}_{30} \mathrm{~K}_{30}$. And only the microscopic population prevailed against the background of $\mathrm{N}_{60} \mathrm{P}_{60} \mathrm{~K}_{60}$ moldboar-surface treatment, and after moldboarnonmoldboar treatment - against the background of $\mathrm{N}_{60} \mathrm{P}_{60} \mathrm{~K}_{60}$ and $\mathrm{N}_{40} \mathrm{P}_{40} \mathrm{~K}_{40}$. 


\section{Conclusions}

Thus, a complex of soil phytopathogenic and saprotrophic biota has been identified in the conditions of the CPR, and the tendency to increase or decrease of their number in grain crops has been experimentally proved. It was revealed that the structure of the population of terricolous pathogens in the agrocenosis of grain crops depends on the methods of tillage and mineral nutrition. The effectiveness of the dose of the applied fertilizer $\mathrm{N}_{60} \mathrm{P}_{60} \mathrm{~K}_{60}$ in reducing and $\mathrm{N}_{30} \mathrm{P}_{30} \mathrm{~K}_{30}$ in increasing the population density of pathogenic microorganisms, depending on the elements of agricultural technology, is shown.

Mycological study of soil samples revealed that the best treatment was the moldboarsurface treatment, which had a stable effect on the entire phytopathogenic complex. However, the most common fungi were saprotrophs for moldboar-nonmoldboar treatment. It was noted that in these treatments, the species of fungi Pythium spp. prevailed, more significantly after the moldboar-surface treatment. After moldboar-nonmoldboar treatment, there was a strong dependence of Helminthosporium micromycetes on Fusarium ones, i.e., if the number of some increased, the number of others decreased.

The information obtained can be used to select the appropriate range of chemicals, to develop protection systems for spring barley in the system of basic tillage.

\section{References}

1. R. Derpsh, K. Moriya, The impact of tillage on crops and ecosystem. Self-regenerating Agriculture based on a systematic approach No-Till, 42 (2005)

2. L. Gi, No-Till field pea cultivation in the Canadian prairies. Self-regenerating Efficient Agriculture, 94 (2006)

3. B. Giuliano, C. Manuela, I. Guido et al, Biologial control May, 72, 38 (2014)

4. V.A. Lavrinova, T.S. Polunina, Dependence of the soil microbiota in apple tree plantations on the degree of moisture and agricultural techniques, 4, 21 (2019)

5. V.A. Lavrinova, T.S. Polunina, I.M. Evseeva. Methodological guide for determining the population of soil with oospores, sclerotia of Pythium spp. - the root rot pathogen, 18 (2015)

6. V.A. Lavrinova, T.S. Polunina, I.M. Evseeva, The state of the population of fungi of the genus Fusarium spp. and determination of their abundance in chernozem soils, 31 (2016)

7. L.M. Poddymkina, The effect of long-term use of chemical agents on the microbiological activity of sod-podzolic soil, 2, 5 (2008)

8. D.G. Baubekova, O.B. Soprunova, Sh.B. Bayrambekov, E.V. Polyakova, Southern Russia: ecology, development, 15(2), 78 (2020)

9. Yu.V. Kruglov, Soil microbial community: Physiological diversity and Research methods, 51(1), 46 (2016)

10. N.I. Frunze, Biomass of soil microorganisms in arable chernozems of Moldova, 3, 92 (2013) 